\title{
Social and Emotional Development of Gifted Students: Introducing the School-Based Psychosocial Curriculum Model
}

Tracy L. Cross

College of William and Mary, tlcross@wm.edu

Jennifer Riedl Cross

College of William and Mary, jrcross@wm.edu

Follow this and additional works at: https://scholarworks.wm.edu/educationpubs

Part of the Gifted Education Commons

\section{Recommended Citation}

Cross, Tracy L. and Cross, Jennifer Riedl, Social and Emotional Development of Gifted Students:

Introducing the School-Based Psychosocial Curriculum Model (2017). Gifted Child Today, 40(3), 178-182.

https://doi.org/10.1177/1076217517713784

This Article is brought to you for free and open access by the School of Education at W\&M ScholarWorks. It has been accepted for inclusion in School of Education Articles by an authorized administrator of W\&M ScholarWorks. For more information, please contact scholarworks@wm.edu. 


\title{
Social and Emotional Development of Gifted Students
}

\author{
Introducing the School-Based Psychosocial Curriculum Model \\ Tracy L. Cross, $\mathrm{PhD}^{1}$ and Jennifer Riedl Cross, $\mathrm{PhD}^{1}$
}

\begin{abstract}
This column introduces the school-based psychosocial curriculum model. The model incorporates Erik Erikson's theory of psychosocial development and applies it to a planned program of talent development.
\end{abstract}

Keywords: gifted children, psychosocial development, talent development, curriculum

I $n$ the education of our nation's students, we often move from one exciting new idea to the next, hoping to find a magic bullet that can transcend the myriad complexities of the teaching and learning process of tens of millions of students from numerous backgrounds across the 50 United States of America. Just a few of the issues and factors that can influence teaching and learning include opportunity to access literacy materials, preschool opportunities, stability of home, access to opportunities to visit and participate in cultural and scientific endeavors in the community, access to mentors, positive role models, access to appropriately trained professional educators, challenge in school, appropriate pacing, English language needs, and possible disabilities to name a few. As we focus on students with gifts and talents (SWGT), we have also learned that differing organizational structures such as flexible ability grouping, self-contained classrooms, and residential academies can offer positive learning outcomes. Moreover, some instructional strategies like curriculum

compacting and problem-based learning have proven quite valuable in the overall school-based learning of SWGT.

In addition to the factors and variables noted above, the community that is concerned with educating students with gifts and talents is evolving away from IQ and other entity conceptions of giftedness to more talent development models that recognize abilities are developed over time in increasingly more focused talent domains. There are numerous factors and influences that contribute to talent development such as good teaching, practice, role models, and so forth. There is a growing

\begin{tabular}{c} 
For ALl \\
STUdENTS \\
(INCLUDING THOSE \\
WITH GIFTS AND \\
TALENTS) TO REACH \\
THEIR POTENTIAL, \\
SIGNIFICANT AND \\
ONGOING DEVELOPMENT \\
IN THE PSYCHOSOCIAL \\
DOMAIN IS NECESSARY." \\
\hline \hline
\end{tabular}
recognition that there are important psychosocial qualities that are critical to developing the highest-level accomplishment by students within talent domains. While that belief is widely held, researchers and practitioners in gifted education have very few theory-driven models of psychosocial development. Valuable constructs have been offered that tend to be rather focused on one or two aspects of psychosocial development (e.g., "growth mind-set"), but there are virtually no large-scale, developmentally oriented theories of psychosocial development that have been applied to the development of talent among students with high ability.

This column expands on a previous Gifted Child Today (GCT) column (Cross, 2001) that provided an introduction to Erik Erikson's Theory of Psychosocial Development. The current column provides an application and expansion of Erikson's theory to talent development. More specifically, the new application focuses on schools and is entitled the school-based psychosocial curriculum model 
Table 1. Erikson's (1963) Stages of Psychosocial Development

\begin{tabular}{|l|l|l|}
\hline Approximate age & \multicolumn{1}{|c|}{ Crisis } & \multicolumn{1}{c|}{ Essential strength } \\
\hline Birth to 1 year & Trust vs. Mistrust & Hope \\
\hline 1 to 3 years & Autonomy vs. Shame and Doubt & Willpower \\
\hline 3 to 6 years & Initiative vs. Guilt & Purpose \\
\hline 6 to 12 years & Industry vs. Inferiority & Competence \\
\hline 12 to 20 years & Identity vs. Role Confusion & Fidelity \\
\hline 20 to 40 years & Intimacy vs. Isolation & Love \\
\hline 40 to 65 years & Generativity vs. Stagnation & Care \\
\hline 65 years and older & Integrity vs. Despair & Wisdom \\
\hline
\end{tabular}

(SPCM). Schools exist to build academic skills that students cannot achieve without the necessary psychosocial skills. Schools are a social context and only with the psychological foundation to engage in social endeavors will students be successful. Erik Erikson's (1963) theory of psychosocial development holds the key.

Erikson's theory describes development as proceeding through stages or crises that arise from tension between the person and her or his environment as the person becomes capable and aware of new abilities. For example, as a toddler becomes capable of running, tension most certainly arises as parents now have to worry about safety and control. In Erikson's crisis of autonomy versus shame and doubt, the toddler must learn a balance between acting willfully and being ashamed or doubtful about his actions. The environment must impose some restrictions for the child's well-being, but too many restrictions will teach the child to always doubt her desire to act and too few will make the child unbearable to be around and, likely, unsafe. Erikson proposed that a healthy balance in the outcome of each crisis - a favorable ratio - would lead to optimal psychological development. Table 1 describes the crises and their approximate ages. We have written about these elsewhere (Cross \& Cross, 2017; Cross, Cross, \& Andersen, 2017).

Erikson saw the resolution of these crises as contributing to a healthy ego, the core sense of the self. As children navigate the psychosocial crises, they develop essential strengths that contribute to a strong ego (see Table 1). Ego in the Eriksonian sense is different from the popular conception of ego, which carries a negative connotation. We want everyone to have strong egos, which will come from a healthy balance between the individuals' desires and abilities and environmental support for them. Gifted students arrive in school having passed through several of the stages, but lessons from psychotherapy teach us that we can still have a positive effect and should not limit our programming to the age at which a crisis is first met.
The SPCM utilizes Erikson's crises as a framework, with "Developing Ego Strength" as the theme. There is no research evidence that SWGT progress through Erikson's stages at a more rapid pace than their age mates, but curriculum developers should keep an open mind to that possibility. In general, however, the image in Figure 1 overlays Erikson's stages on the approximate age ranges when they may appear: preschool, elementary, and secondary. Curriculum and professional development can be generated from this model to build ego strength among SWGT.

\section{Creating a Planned Program of Psychosocial Development}

A school-based program designed to support the development of ego strength should address the crises from Trust versus Mistrust to Intimacy versus Isolation, through both professional development for teachers and counselors and direct instruction for SWGT. In Cross and Cross (2017), we recommended that the ideal starting point in planning such a program is in the essential strength of fidelity, the outcome of the crisis Identity versus Role Confusion. We offer an example of how we might begin to apply the SPCM. If we desire to help a SWGT in adolescence or early adulthood to view him- or herself as a research mathematician, prepared to take on a challenging college curriculum with the long hours of difficult work that will go into being successful, certain lessons are recommended by Erikson's theory. First, the essential strength of hope will be nurtured if the student has learned at some point how to put her or his confidence in others who will have the student's best interest in mind. A lesson in how to recognize those who can be trusted as supporters and those who will be unsupportive or even oppositional will provide an important foundation for gifted students at any age. Self-soothing techniques will help a SWGT learn how to take care of him- or herself during times of stress, which she or he is sure to 


\section{Psychosocial Objective: Favorable Ratio}

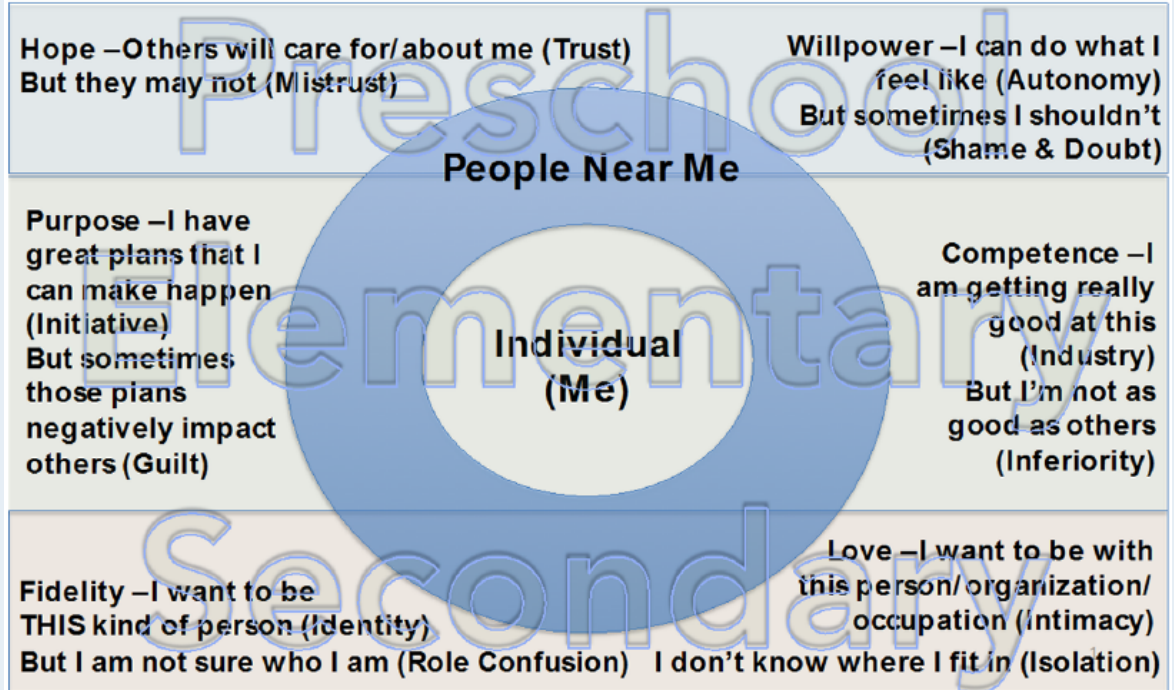

Figure 1. Conceptualizing the SPCM.

\section{Favorable Ratio $=$ Healthy Balance}
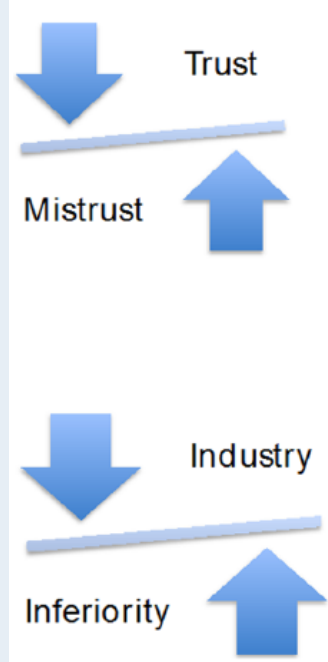
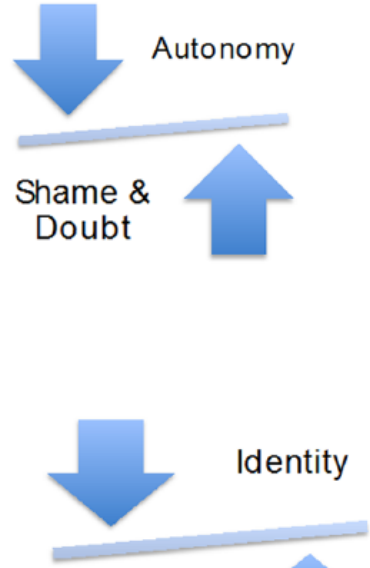

Role Confusion
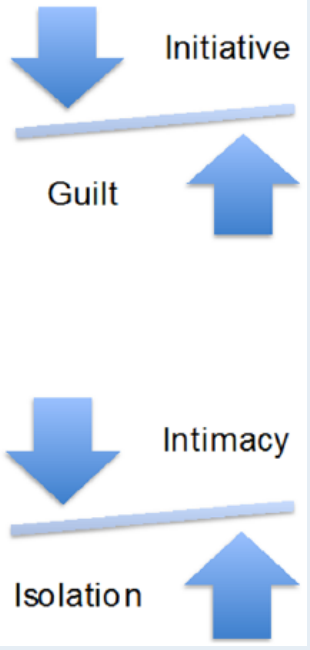

Figure 2. Fostering a favorable ratio of each crisis through the SPCM. Note. SPCM = school-based psychosocial curriculum model.

experience on the road to becoming a research mathematician. Lessons in how to find and talk openly with a counselor will help the SWGT deal with more significant psychological distress, giving her or him the hope needed to be successful.
Professional development that addresses the crisis of Trust versus Mistrust will enlighten teachers to the needs of their highly capable students-that they may recognize and be responsive to them. When students discover they can trust their 
Table 2. Possible Lessons From Issues and Themes Suggested by Erikson's Psychosocial Crises

\begin{tabular}{|c|c|c|}
\hline Essential strength & Crisis-Positive & Crisis-Negative \\
\hline \multirow[t]{3}{*}{ Hope } & Trust & Mistrust \\
\hline & Identify internal resources & $\begin{array}{l}\text { Identify resources and barriers (e.g., supporters } \\
\text { and nonsupporters) }\end{array}$ \\
\hline & Self-soothing & How to participate in counseling \\
\hline \multirow[t]{3}{*}{ Willpower } & Autonomy & Shame and doubt \\
\hline & Persistence & Letting go \\
\hline & Creative ways to pursue desires & Recognizing impact on others \\
\hline \multirow[t]{6}{*}{ Purpose } & Initiative & Guilt \\
\hline & Goal setting & Realistic goal setting \\
\hline & Self-advocacy & Avoiding narcissism, egotism \\
\hline & Being yourself & Considering others \\
\hline & Developing passion & Developing balance \\
\hline & Working alone & Cooperation/working in groups \\
\hline \multirow[t]{6}{*}{ Competence } & Industry & Inferiority \\
\hline & Identifying interests & Trying new things \\
\hline & Your social goals & Others' social goals \\
\hline & Succeeding & Failing (positive) \\
\hline & Accepting/pursuing challenge & Big-Fish-Little-Pond-Effect \\
\hline & Practice & Entity beliefs \\
\hline \multirow[t]{6}{*}{ Fidelity } & Identity & Role confusion \\
\hline & Knowing own/family/community values & Learning about others' values \\
\hline & Career development & Multipotentiality \\
\hline & Authenticity & Possible selves \\
\hline & Self-concept & Reputation \\
\hline & Being yourself & Information Management Model (e.g., code-switching) \\
\hline \multirow[t]{4}{*}{ Love } & Intimacy & Isolation \\
\hline & $\begin{array}{l}\text { Identifying opportunities commensurate } \\
\text { with one's values }\end{array}$ & Learning the requirements of one's role in a group \\
\hline & Leadership training & Servant leadership \\
\hline & $\begin{array}{l}\text { Features of positive romantic } \\
\text { relationships }\end{array}$ & Features of negative romantic relationships \\
\hline
\end{tabular}

Source. Adapted from Cross, Cross, and Andersen (2017). 
teachers to take them seriously, to care about their boredom and give them positive attention, the balance of the lesson will tip toward Trust. To achieve a favorable ratio, they should also know that their teachers will not always understand their questions or their desire to learn more, will be too busy to attend to their boredom, and cannot always respond to their needs. In this example, they can develop hope if they learn to cope with the ways in which their environment cannot provide for them. Lessons suggested by this example would include strategies for dealing with a too-busy teacher or boredom in the classroom. Rather than feeling hopeless that the world is against them, the SWGT with ego strength will have hope that she or he can trust that her or his needs will be met, but will know what to do when they inevitably will not.

Each crisis can be examined in a similar way to the example above. How can a favorable ratio, with a tip toward the positive side, be achieved (see Figure 2) in each of the crises? A planned program designed to consider both sides of the crises should include both intrapersonal (within the SWGT; the "Individual" in Figure 1) and interpersonal (with others; the "People near me" in Figure 1) components. The objective is to achieve a balanced perspective, leading to ego strength. At different ages, SWGT will experience different interpersonal issues. For example, young SWGT may enjoy helping their peers, but the expectation that they will help can become burdensome as their own workload increases. An age-appropriate lesson would take such differences into consideration. Table 2 describes possible lessons for each of the essential strengths.

Talent development requires a strong ego. SWGT must be motivated and able to pursue the goals necessary to achieve their maximum potential. The brief description provided here is intended to whet the appetite of those wishing to foster the psychosocial skills of their students. We encourage you to read more in Cross et al. (2017) and Cross and Cross (2017). We hope that the SPCM will provide an easy to use guide for developing curriculum in the psychosocial domain. For all students (including those with gifts and talents) to reach their potential, significant and ongoing development in the psychosocial domain is necessary.

\section{Conflict of Interest}

The author(s) declared no potential conflicts of interest with respect to the research, authorship, and/or publication of this article.

\section{Funding}

The author(s) received no financial support for the research, authorship, and/or publication of this article.

\section{References}

Cross, T. L. (2001). Social/emotional needs: Gifted children and Erikson's theory of psychosocial development. Gifted Child Today, 24(1), 54-55.

Cross, T. L., \& Cross, J. R. (2017). Maximizing potential: A school-based conception of psychosocial development. High Ability Studies. Advance online publication. doi:10.1080/13598139.2017.1292896

Cross, T. L., Cross, J. R., \& Andersen, L. (2017). The school-based psychosocial curriculum model. In J. VanTassel-Baska \& C. A. Little (Eds.), Content-based curriculum for bigh-ability learners (3rd ed., pp. 383-407). Waco, TX: Prufrock Press.

Erikson, E. H. (1963). Childhood and society (2nd ed.). New York, NY: W.W. Norton.

\section{Bios}

Tracy L. Cross, PhD, is the Jody and Layton Smith professor of psychology and gifted education, and serves as the executive director of the Center for Gifted Education at the College of William \& Mary. He is the current editor of the Journal for the Education of the Gifted. He can be reached at TLCross@wm.edu.

Jennifer Riedl Cross, $\mathrm{PhD}$, is the director of research at the William \& Mary Center for Gifted Education, where she writes grants and coordinates and conducts research. She teaches educational psychology and research methods courses in the William \& Mary School of Education. 
Copyright of Gifted Child Today is the property of Sage Publications Inc. and its content may not be copied or emailed to multiple sites or posted to a listserv without the copyright holder's express written permission. However, users may print, download, or email articles for individual use. 